\title{
Konservasi Buaya Muara di Taman Margasatwa Semarang
}

\section{Evi Setyowati, Sri Ngabekti ${ }^{\bowtie}$, dan Bambang Priyono}

Jurusan Biologi, Fakultas Matematika dan Ilmu Pengetahuan Alam Universitas Negeri Semarang, Indonesia

\section{Info Artikel}

Diterima: 1 Maret 2019

Disetujui: 30 Maret 2019

Dipublikasikan: 25 April

2019

\section{Keywords:}

estuarine crocodiles,

conservation success,

conservation methods,

buaya muara, keberhasilan

konservasi, metode konservasi.

\begin{abstract}
Stuary crocodile (Crocodylus porosus) is one of the fauna that is protected by Indonesian law because of its high economic value. Publications regarding the success of estuarine crocodile conservation are still small. Efforts can be made to prevent the extinction of estuarine crocodiles through conservation. Semarang Wildlife Park is an ex-situ conservation institution that has succeeded in breeding estuarine crocodiles. This study aims to examine the methods of estuarine crocodile conservation, factors in conservation methods, and the success rate of estuarine crocodile conservation in Semarang Wildlife Park. The research methods used were observation, interviews, and documentation. The research data were analyzed by quantitative descriptive analysis. The results showed that the method of estuarine crocodile conservation in Semarang Wildlife Park took the form of breeding activities consisting of management of housing, feed, health, and breeding. The factors that influence conservation success are cage, feed, and weather. The level of success of estuarine crocodile conservation in Semarang Wildlife Park seen from the aspect of DTT $55.4 \%$ and MR 29\% with criteria quite successful. Suggestions that can be conveyed are Need to do further research on measuring the temperature and humidity of the soil used as nest of estuarine crocodile eggs in the aspect of egg hatching that affect the success of conservation and more intensive management of estuarine crocodile breeding activities in Semarang Wildlife Park for successful conservation.
\end{abstract}

\begin{abstract}
Abstrak
Buaya muara (Crocodylus porosus) merupakan salah satu fauna yang dilindungi perundangundangan Indonesia karena bernilai ekonomi tinggi. Publikasi mengenai keberhasilan konservasi buaya muara masih sedikit. Upaya yang dapat dilakukan untuk mencegah kepunahan buaya muara adalah melalui konservasi. Taman Margasatwa Semarang merupakan lembaga konservasi secara $e x$-situ yang telah berhasil mengembangbiakkan buaya muara. Penelitian ini bertujuan untuk mengkaji metode konservasi buaya muara, faktor-faktor dalam metode konservasi, serta tingkat keberhasilan konservasi buaya muara di Taman Margasatwa Semarang. Metode penelitian yang digunakan adalah observasi, wawancara, dan dokumentasi. Data hasil penelitian dianalisis secara analisis deskriptif kuantitatif. Hasil penelitian menunjukkan bahwa metode konservasi buaya muara di Taman Margasatwa Semarang berupa kegiatan penangkaran yang terdiri dari pengelolaan perkandangan, pakan, kesehatan, dan perkembangbiakan. Faktor-faktor yang mempengaruhi keberhasilan konservasi adalah kandang, pakan, dan cuaca. Tingkat keberhasilan konservasi buaya muara di Taman Margasatwa Semarang dilihat dari aspek DTT 55,4\% dan MR $29 \%$ dengan kriteria cukup berhasil. Saran yang dapat disampaikan adalah Perlu dilakukan penelitian lebih lanjut mengenai pengukuran suhu dan kelembapan tanah yang digunakan sebagai sarang telur buaya muara dalam aspek penetasan telur yang mempengaruhi keberhasilan konservasi dan Perlu dilakukan pengelolaan lebih intensif mengenai kegiatan penangkaran buaya muara di Taman Margasatwa Semarang agar keberhasilan konservasinya meningkat.
\end{abstract}




\section{PENDAHULUAN}

Di Indonesia dikenal empat jenis buaya yaitu Tomistoma schlegelii, Crocodylus siamensis, Crocodylus novaeguineae, Crocodylus porosus. Keempat jenis buaya tersebut dilindungi oleh undang-undang berdasarkan Surat Keputusan Menteri Pertanian Nomor 327/Kpts/Um/5/1978 dan Nomor 716/Kpts/Um/10/1980 (Ripai et al., 2016). Menurut Peraturan Pemerintah Republik Indonesia Nomor 7 Tahun (1999) mengenai jenis-jenis tumbuhan dan satwa yang dilindungi, satwa reptilia buaya muara merupakan salah satu buaya dengan status dilindungi oleh Negara Republik Indonesia.

Secara historis penduduk Indonesia telah memanfaatkan buaya muara untuk berbagai tujuan non-komersial. Penduduk asli Papua berburu buaya muara secara tradisional hanya mendapatkan tambahan protein hewani dalam menu makan mereka. Pemanfaatan buaya muara untuk tujuan komersial oleh penduduk asli Papua merupakan fenomena yang berlangsung sekitar tahun terakhir, yaitu sejak Pemerintah Indonesia melihat bahwa komersialisasi buaya muara dengan memanfaatkan kulitnya merupakan kontribusi yang nyata untuk meningkatkan perekonomian masyarakat lokal dan Propinsi Papua secara keseluruhan. Buaya muara termasuk satwa liar yang dilindungi, maka keberhasilan konservasi buaya muara dengan berprinsip pada pemanfaatan berkelanjutan diperlukan strategi manajemen yang cocok dan dapat mudah diterapkan pada budaya masyarakat (Kurniati, 2008).

Manfaat dari buaya muara yaitu daging yang dapat digunakan sebagai sumber protein yang tinggi, kulit, dan bagian tubuh buaya yang lain seperti lemak, empedu, tengkur, gigi, dan juga kuku. Bagian kuku dan gigi dari buaya muara dapat dijadikan sebagai aksesoris sedang bagian empedu, tangkur dan lemaknya dijadikan untuk obat tradisional. Kulit buaya muara dapat dimanfaatkan sebagai kerajinan tangan seperti tas, ikat pinggang, sepatu, jaket (Arifin, 2008).

Menurut Sarwono (2010) nilai ekonomi tinggi inilah yang menyebabkan permintaan terhadap buaya muara terus meningkat setiap tahunnya. Hal ini menimbulkan rangsangan kepada masyarakat untuk mengeksploitasi buaya muara sebanyak mungkin dari alam. Penangkapan dan perburuan terhadap buaya muara merupakan salah satu penyebab utama kepunahan, oleh karena itu perlu dilakukan upayaupaya perlindungan, salah satunya melalui kegiatan Lembaga Konservasi Buaya muara agar eksploitasi Buaya muara dari alam dapat dikurangi sehingga kelestariannya dapat terus dijaga.

Berkurangnya populasi buaya muara disebabkan oleh beberapa faktor antara lain yaitu kerusakan habitat, perburuan secara liar, dan lemahnya pengetahuan dari masyarakat setempat mengenai konservasi lingkungan khususnya untuk Buaya muara. Menurut Ripai et al., (2016), konservasi merupakan upaya untuk melindungi, mempertahankan, serta melestarikan satwa. Konservasi dapat dibedakan menjadi dua yaitu konservasi in-situ dimana konservasi dilakukan dihabitat aslinya, dan konservasi ex-situ dimana konservasi dilakukan di luar habitat aslinya.

Konservasi adalah langkah-langkah pengelolaan satwa liar dalam rangka memenuhi kebutuhan generasi saat ini dan generasi masa mendatang. Konservasi ex-situ adalah konservasi satwa yang dilakukan di luar habitatnya. Lembaga Konservasi merupakan lembaga yang bergerak dibidang 
konservasi satwa liar di luar habitatnya (ex-situ), baik berupa lembaga pemerintah maupun lembaga nonpemerintah (Peraturan menhut No P. 31/Menhut-II/2012).

Taman Margasatwa merupakan salah satu Lembaga Konservasi Ex-situ dengan melakukan

kegiatan penangkaran buaya muara. Penelitian mengenai konservasi ex-situ di Taman Margasatwa sebagai Lembaga Konservasi masih sangat terbatas, dan mengenai publikasi keberhasilan dalam konservasi satwa secara ex-situ juga masih sangat jarang dilakukan.

Berdasarkan studi pendahuluan (Januari, 2018) bahwa satwa reptilia yang ada di Taman Margasatwa Semarang dalam kategori dilindungi dan terancam punah keberadaannya adalah buaya muara. Bayi buaya yang berhasil ditetaskan pada tahun 2017. Bulan Februari tahun 2018 diperoleh data jumlah buaya muara jantan sebanyak tiga dan betina hanya ada satu dan pada tahun 2017 berhasil ditetaskan 36 bayi buaya muara. Berdasarkan latar belakang di atas, penting dilakukan penelitianyang bertujuan untuk mengkaji: metode konservasi buaya muara, (2) faktor-faktor yang mempengaruhi tingkat keberhasilan konservasi buaya muara, dan (3) tingkat keberhasilan buaya muara dalam metode kenservasi buaya muara di Taman Margasatwa Semarang.

\section{METODE}

Data yang dikumpulkan pada penelitian mencakup dua kategori yaitu data primer dan data sekunder. Pengumpulan data dilakukan dengan metode observasi lapangan, wawancara, studi literatur dan dokumentasi. Data mengenai aspek penetasan, pembesaran, perkandangan, pemberian pakan, dan perawatan kesehatan buaya muara dianalisis secara deskriptif kuantitatif dan kualitatif. Indikator keberhasilan konservasi buaya muara dari aspek reproduksi apabila dapat menghasilkan keturunan. Analisis kuantitatif dilakukan untuk menghitung faktor biologis satwa yang meliputi daya tetas telur dan angka kematian anakan buaya muara (Peraturan Menteri Kehutanan Nomor P.19/Menhut-II/2005 tentang penangkaran tumbuhan dan satwa liar). Analisis kesejahteraan buaya di Lembaga Konservasi ditentukan dengan menelaah praktik pengelolaan buaya muara yang dikaitkan dengan prinsip kesejahteraan satwa (Animal Welfare) (Ripai et al., 2016).

\section{HASIL DAN PEMBAHASAN}

\section{Metode Konservasi Buaya Muara di Taman Margasatwa Semarang}

Lembaga Konservasi Ex-situ merupakan salah satu upaya perkembangbiakan yang dilakukan di luar habitat aslinya dan dibuatkan kandang sedemikian rupa menyerupai habitat aslinya, agar upaya konservasi berhasil dibutuhkan suasana habitat yang mirip dengan habitat alaminya. Jumlah kandang buaya muara yang terdapat di Taman Margasatwa Semarang sebanyak 6 kandang yang berisi jumlah dan ukuran buaya yang berbeda.

Buaya muara yang baru lahir di Taman Margasatwa Semarang biasanya diletakkan dalam akuarium atau box besar dengan diisi sedikit air dan enceng gondok. Jenis makanan yang diberikan pada buaya muara di Taman Margasatwa Semarang terdiri dari dua macam yaitu mangsa hidup dan mangsa 
mati. Mangsa hidup untuk buaya muara umur $>1$ bulan sampai umur 2-3 bulan karena buaya muara yang baru lahir umur 2-3 bulan akan mencari makanan yang bergerak. Mangsa mati untuk buaya muara umur $>3$ bulan yaitu berupa daging ayam yang sudah bersih, sapi, dan ikan. Jenis makanan di Taman Margasatwa Semarang diberikan sesuai ketersediaan yang ada. Buaya muara yang baru lahir sampai umur satu bulan tidak diberi makan apapun, karena masih memiliki cadangan makanan berupa kuning telur yang terdapat di perut bayi buaya muara. Bentuk makanan yang diberikan pada buaya muara di Taman Margasatwa Semarang terdiri dari 2 macam bentuk yaitu cincang untuk buaya muara belum dewasa dan utuh untuk buaya muara sudah dewasa. Jadwal pemberian pakan buaya muara dilakukan satu minggu sekali setiap hari Senin.

Jumlah pakan sudah mencukupi untuk melakukan aktivitas dengan adanya perilaku agresif dari buaya muara yang tidak terlihat kelaparan. Jumlah pakan pada buaya muara sampai dengan indukan produktif masih kurang dengan kebutuhan yang seharusnya diberikan, namun berdasarkan pengamatan kondisi buaya muara terlihat dalam keadaan baik tidak terlihat kekurangan pakan.

Sistem pemberian pakan buaya muara di Taman Margasatwa Semarang tidak terdapat kendala dalam hal jenis, bentuk ataupun jadwal pemberian pakan. Hanya saja terkadang pada kandang yang berisi banyak buaya muara seperti pada kandang 2 (17 ekor) jumlah pakan menjadi sedikit kendala karena mengakibatkan pertengkaran memperebutkan pakan dan karena sistem koloni kecil buaya muara dimana pemimpin harus makan terlebih dahulu, jadi jika pemimpin belum makan yang lain tidak boleh makan. Pertengkaran yang terjadi akibat memperebutkan makanan mengakibatkan kematian, terkadang ada buaya muara yang tidak mendapat makan dan akhirnya mati. Pertengkaran memperebutkan makan juga terkadang mengakibatkan trauma pada buaya, sehingga buaya muara tidak makan dan akhirnya mati.

\section{a. Penyakit dan Kesehatan}

Secara umum buaya muara buaya muara adalah jenis satwa reptil yang kebal terhadap serangan penyakit. Tidak pernah ada kasus penyakit yang menyebabkan kematian buaya muara di Taman Margasatwa Semarang. Kematian yang terjadi disebabkan karena perkelahian antar buaya. Alat dan obat penunjang kesehatan buaya muara di Taman Margasatwa Semarang yang tersedia hanyalah perban dan obat merah untuk pengobatan, tidak ada kasus penyakit berarti yang menyebabkan kematian buaya muara di Taman Margasatwa Semarang.

\section{b. Perkembangbiakan Buaya Muara}

Buaya muara di Taman Margasatwa Semarang melakukan kopulasi di dalam kolam dan sulit dideteksi. Posisi buaya muara saling bertindih dengan posisi ekor saling bertemu yang dilakukan di dalam kolam berair dengan tujuan sperma buaya muara jantan membuahi sel telur induk buaya muara betina. Jadi air kolam yang ada di dalam kandang tidak boleh sampai surut bahkan harus lebih banyak dari biasanya. Musim kawin buaya muara di Taman Margasatwa Semarang biasanya terjadi antara bulan Agustus sampai Oktober, karena pada bulan tersebut mempunyai suhu yang optimal untuk menetaskan telur. Suhu optimal untuk menetasan telur buaya muara antara $29.4^{\circ} \mathrm{C}$ dan $32.6^{\circ} \mathrm{C}\left(30.9 \pm 2.3^{\circ} \mathrm{C}\right)$, dan hal ini tidak dipengaruhi oleh situasi sosial atau status makanan (Brien, 2015). 
Induk betina menyimpan telur-telurnya dengan membenamkannya di tanah dan ditutup dengan seresah daun dan ranting kecil yang jatuh. Sarang telur dibuat induk di gundukan tanah yang lebih tinggi dari kolam induk dan kolam kandang. Masa menjaga telur oleh induk di gundukan dengan air tidak akan terlalu banyak, agar jika hujan sarang tidak akan terendam air yang mengakibatkan telur buaya busuk dan gagal menetas.

Faktor lingkungan air: suhu berkisar antara $30-32^{\circ} \mathrm{C}$, kelembapan $40-68 \%$, dan $\mathrm{pH}$ 7. Suhu untuk menetasan telur buaya muara antara $30^{\circ} \mathrm{C}$ sampai $34^{\circ} \mathrm{C}$ dengan kelembapan antara $40 \%$ sampai $68 \%, \mathrm{pH}$ 7. Dengan kondisi faktor lingkungan tersebut buaya muara di Taman Margasatwa Semarang mampu beradaptasi dan telah berhasil berkembangbiak sejak tahun 2011. Bradford (2014) menyatakan bahwa suhu yang optimum bagi telur untuk menetas adalah sebesar $31.6^{\circ} \mathrm{C}$ dan betina diproduksi ketika suhu di bawah 82,4 derajat Fahrenheit (28 derajat Celcius), dan jantan diproduksi pada suhu di atas 91,4 $\mathrm{F}\left(33^{\circ} \mathrm{C}\right)$.

\section{Faktor-Faktor Keberhasilan Konservasi Buaya Muara di Taman Margasatwa Semarang}

Faktor-faktor yang mempengaruhi keberhasilan konservasi buaya muara adalah kandang, pakan, dan cuaca. Kandang merupakan hal yang penting dalam melakukan konservasi ex-situ. Keberhasilan konservasi dipengaruhi oleh jumlah kandang, karena semakin banyak kelahiran maka seharusnya semakin banyak pula kandang. Hal ini disebabkan buaya dengan umur dan ukuran berbeda, tidak dapat diletakkan dalam satu kandang agar tidak menimbulkan konflik fisik berupa perkelahian. Dampak perkelahian adalah kematian.

Pakan juga merupakan fakror yang menentukan keberhasilan konservasi. Pemberian pakan buaya muara di Taman Margasatwa Semarang tidak terdapat kendala dalam hal jenis, bentuk ataupun jadwal pemberian pakan. Hanya saja terkadang pada kandang yang berisi banyak buaya muara seperti pada kandang 2 (17 ekor) jumlah pakan menjadi sedikit kendala karena terjadi pertengkaran merebutkan pakan. Sistem pembentukan koloni kecil buaya muara, pemimpin harus makan terlebih dahulu, yang lain tidak boleh makan. Pertengkaran yang terjadi akibat memperebutkan makanan mengakibatkan kematian. Terkadang ada buaya muara yang tidak mendapat makan dan akhirnya mati. Pertengkaran memperebutkan makan juga terkadang mengakibatkan trauma pada buaya, sehingga buaya muara tidak makan dan akhirnya mati.

Cuaca merupakan faktor yang mempengaruhi keberhasilan konservasi buaya muara di Taman Margasatwa Semarang. Cuaca hanya terjadi dalam waktu singkat yang disebabkan oleh adanya perbedaan suhu dan kelembapan. Unsur-unsur cuaca diantaranya adalah suhu dan kelembapan. Hujan merupakan hasil akhir dari perpaduan unsur-unsur cuaca. Cuaca hujan sangat mempengaruhi penetasan buaya muara. Tahun 2015 dan 2016 penetasan telur gagal karena membusuk akibat tanah basah oleh air hujan disertai air kolam meluap sehingga mengakibatkan sarang buaya terendam air dalam kurun waktu yang cukup lama.

Penelitian Magnusson (1982) mengenai mortalityof eggs of the crocodile crocodylus porosus in Northern Australia menyatakan bahwa sebagian besar kematian telur buaya di Australia disebabkan oleh 
banjir, banjir ada dua jenis yaitu banjir jangka pendek yang disebabkan oleh interaksi curah hujan dan gerakan pasang surut dan banjir jangka panjang yang disebabkan oleh hujan lebat.

\section{Tingkat Keberhasilan Konservasi Buaya Muara di Taman Margasatwa Semarang}

Telur buaya muara menetas setelah telur dibiarkan berada di sarang yang telah dibuat induknya dalam kurun waktu \pm 3 bulan. Buaya muara yang baru menetas akan membuat suara kicau, yang memicu induk untuk menggali bayi buaya muara keluar dari sarang. Hal ini sesuai dengan pernyataan Kumar et al. (2012) bahwa telur biasanya menetas setelah sekitar 90 hari.

Telur buaya muara di Taman Margasatwa Semarang dibiarkan berada di sarang, namun ketika akan menetas \pm 7 -10 hari telur akan diambil oleh petugas agar telur bisa menetas dengan baik, tidak tertindih indukan. Menurut Kusyanto (komunikasi pribadi), pada tahun 2017 induk buaya muara akan semakin mendekati sarangnya. Usaha ini dilakukan juga untuk menghindari induk buaya muara memakan anakan buaya muara setelah menetas.

Telur yang telah dipindahkan, diletakkan ke dalam ember dan ditimbun di bawah pasir untuk menjaga suhu sesuai dengan suhu penetasan yaitu $\pm 31^{\circ} \mathrm{C}$. Buaya muara harus menetas dengan sendirinya, tidak boleh dipaksa keluar walaupun cangkang telurnya sudah pecah. Jika dipaksa keluar dengan kondisi bayi buaya muara belum beradaptasi maka akan mengakibatkan kematian setelah menetas. Data penetasan telur dari tahun 2011-2017 tersaji dalam Gambar 1.

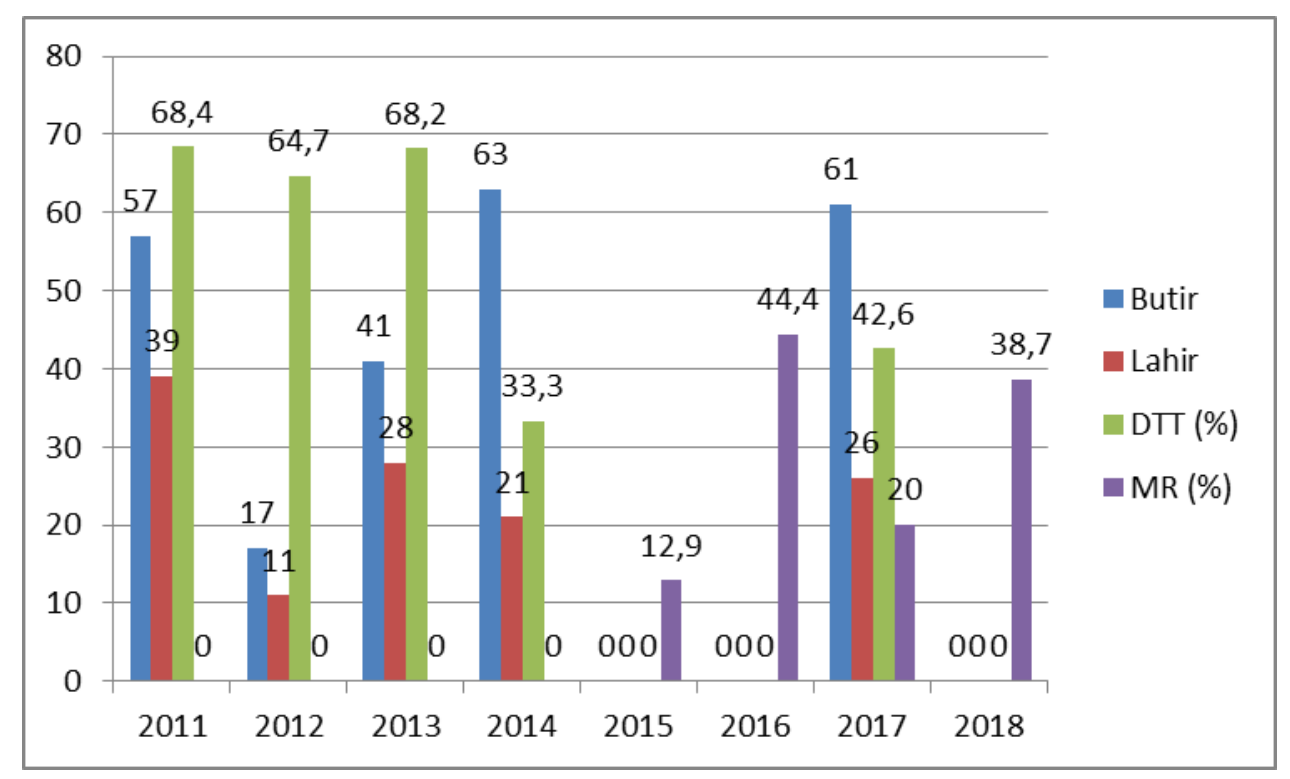

Gambar 1. Grafik penetasan telur dari tahun 2011-2017 (Setyowati et al., 2018)

Kriteria keberhasilan konservasi buaya muara di Taman Margasatwa Semarang dari aspek persentase Daya Tetas Telur (DTT) dan persentase kematian (MR) a. 0\% - 30\% : Rendah, b. 31\% - 60\%: Sedang, c. $\geq 61 \%$ : Tinggi.

Tingkat mortalitas buaya muara juga sangat tinggi karena dari $25 \%$ telur yang menetas hanya $54 \%$ dari yang muda akan bertahan hidup sampai satu tahun (Kumar et al., 2012). Konservasi buaya 
muara di Taman Margasatwa Semarang berdasarkan aspek reproduksi dikategorikan menjadi kriteria kualitatif hasilnya adalah berhasil. Dari aspek DTT $=55.4 \%$ (sedang) dan MR $=29 \%$ (rendah) dapat disimpulkan bahwa konservasi buaya muara cukup berhasil.

\section{SIMPULAN}

Metode konservasi buaya muara di Taman Margasatwa Semarang berupa kegiatan konservasi ex-situ melalui penangkaran. Faktor-faktor yang mempengaruhi keberhasilan konservasi yaitu kandang, pakan, cuaca. Tingkat keberhasilan konservasi buaya muara cukup berhasil.

\section{DAFTAR PUSTAKA}

Arifin. (2008). Crocodile Husbandary in Papua New Guinea. FAO. Port Moresby.

Bradford. (2014). Facts About Alligators. Live Science Contributor.

Brien, \& Matthew L. (2015). Growth and Survival of Hatchling Saltwater Crocodiles (Crocodylus porosus) in Captivity: The Role of Agonistic and Thermal Behavior. University of Queensland.

Kumar, Akhilesh, Yasmin K., Yasmin F.Z., \& Amita K. (2012). A Review on Status and Conservation of Saltwater Crocodile (Crocodylus porosus) in India. International Day for Biological Diversity: Marine biodiversity.

Kurniati, \& Hellen. (2008). Pembesaran dan Penangkaran Buaya Jenis Buaya Muara Crocodylus porosus dan Buaya Air Tawar Irian Crocodylus navaguineae. Cibinong: LIPI.

Magnusson, \& William E. (1982). Mortality of The Crocodile Crocodylus Porosus in Northern Australia. Journal of Herpetology, 16(2), 121-130.

Peraturan Menteri Kehutanan Nomor P.19/Menhut-II/2005 Tentang Penangkaran Tumbuhan dan Satwa Liar.

Peraturan Menteri Kehutanan Republik Indonesia Nomor: P.31/Menhut-II/2012 Tentang Lembaga Konservasi.

Peraturan Pemerintah Nomor 7 Tahun 1999 Tentang Pengawetan Jenis Tumbuhan dan Satwa.

Ripai, Ahmad \& Legowo K. (2016). Penangkaran Buaya Muara (Crocodylus porosus) di PT. Makmur Abadi Permai Samarinda Kalimantan Timur. Jurnal AGRIFOR, 2(15), 155-170.

Sarwono. (2010). Pemanfaatan Crocodylus porosus. Indonesia: Pustaka Jaya. 